\title{
THE DESIGN OF RESULTANT FORCE VECTOR TEACHING AIDS FOR SENIOR HIGH SCHOOL STUDENTS
}

\author{
Bambang Subali*1, Firda Nikmah ${ }^{2}$, Imam Sumpono ${ }^{3}$, Siswanto ${ }^{4}$ \\ 1, 2, 3 Physics Education, Faculty of Mathematics and Natural Science, Universitas Negeri Semarang, Indonesia \\ ${ }^{4}$ Department of Natural Science Education, Universitas Tidar Magelang, Indonesia \\ *Corresponding Authors. E-mail: bambangfisika@mail.unnes.ac.id
}

Received: January $11^{\text {st }}, 2019$. Accepted: April 22 $2^{\text {nd }}, 2019$. Published: April 29 $9^{\text {th }}, 2019$

\begin{abstract}
Abstrak: This study aims to create the design of resultant force vector teaching aids to improve students' conceptual understandings. The method of this study is the experimental method with Pretest-Posttest Control Group Design. The sample of this study is the tenth grade of 3 natural science class (X IPA 3) as the experimental class and the tenth grade of 4 natural science class (X IPA 4) as the control class at 1 Subah Senior High School. The vector teaching aids were tested for the validity by the validator using a questionnaire. The students' responses were measured using a questionnaire. The students' concept understandings were measured from the results of the pretest and posttest scores. The result of the teaching aids' feasibility test is $98.61 \%$, showing that the teaching aids are very feasible to use. The increase of students' concept understandings measured by the students' learning outcomes in the experimental class after using the resultant force vector teaching aids is 0.7 included in the high category. The attitude and interest responses of the students after using the teaching aids get an average percentage of $71.06 \%$ included in the high category. Based on the research results, it is recommended for the teachers to utilize the environment to create real learning.
\end{abstract}

C 2019 Physics Education, UIN Raden Intan Lampung, Indonesia

Keywords: concept understanding, students' responses, vector teaching AIDS

\section{INTRODUCTION}

Education is a contribution to the progress and development of the world. It is one of the efforts to create high-quality and useful human resources (Sulisworo, 2016). It aims to make human beings qualified and characterized in order to be able to adapt to the surrounding community and to create broader views to create a more advanced world (Korsun, 2017). Physics learning at schools does not assess from an end product but focus on a process to obtain natural science with a meaning (Anggereni \& Ikbal, 2018).

Physics is a study of the universe that occurs in everyday life and a part of empirical science (Anwar et al., 2019). Thus, to solve problems in physics, the students must be able to understand the concepts of the material. Most students do not like learning physics because they only memorize the material formulations without understanding the concepts in every material, physics should not be learned by memorizing but understanding concepts (Billah \& Widiyatmoko, 2018).
According to (Billah \& Widiyatmoko, 2018) "Physics as a branch of natural science basically aims to study and provide information about laws, theories, principles, facts from various natural phenomena". Physics learning will be easier and more meaningful if the students are able to associate or utilize existing natural phenomena in the surrounding environment by linking the phenomena to physics (Widayanti, Abdurrahman, \& Suyatna, 2019). In this process, the students will have the ability to observe and experiment directly by emphasizing their ability to think and work scientifically (Psycharis, 2016).

Physics has relevance to mathematics because mathematics is the study of forms, structures, quantities, and concepts related to one theory with another (Kusuma Wardani, 2016). Thus, mathematics is able to provide a framework for the formulation of the laws of physics, so understanding the concept of physics is very important for the students, not only memorizing the concepts but also having to understand the 
concepts, being able to understand the concepts, the students are able to explain the problems in daily life (Handhika \& Kurniadi, 2016; Maharani, Rahayu, Amaliah, Rahayu, \& Saregar, 2019).

Developing students' interest in learning and increasing students' conceptual understandings are very important in order to achieve the learning objectives. The physics learning process should use experimental learning methods to increase students' conceptual understandings or students' learning outcomes (Berszán, 2016). By utilizing the experimental learning methods, the students will be able to develop their skills, conclude and connect an old concept with a new concept. By experimenting, the students experience a real practice of the material or material (Okono, 2015).

Teaching aids do not have to be expensive. Teaching aids as tools to facilitate students in learning can be made by recycling or utilizing the surrounding unused materials (Widayanti \& Yuberti, 2018). The teaching aids are made to support the learning process of the students so that they are able to understand the theories or concepts well, to make students attractive during the learning process, and to trigger the students' curiosity (Zahara, Haji, \& Syukri, 2018).

One of the topics in physics learning is vector. This material covers a topic, namely vector drawing, vector addition, vector reduction, determining the resultant vector graphically and analytically. In this lesson, the students must be able to understand a concept because the vector material does not have any formula to memorize (Gire \& Price, 2014). The students must also be able to describe a vector. If the students do not understand the concept, they will have difficulty in working on the problem. In working on the problem or learning process, they do not start with free diagrams (drawing the vector directions). They avoid drawing the diagram because they prefer to memorize the components in the diagram rather than geometrically derivative (Wutchana, Bunrangsri, \& Emarat, 2015).

According to (Smith, Wittmann, \& Carter, 2014), there are many difficulties for students to understand the vector material, especially in the analytical subchapter. This is because the students have not received trigonometric material in mathematics learning. In this vector chapter, they must be able to analyze each angle formed by a vector and decipher the components of several formed vectors (Wutchana et al., 2015).

Based on the results of observations and interviews with the teachers at 1 Subah High School conducted to find out the potential at school and the problems being faced by the teacher during the learning process in the classroom (Girvan, Conneely, \& Tangney, 2016). The observations in the physics laboratory at the school are lack of tools. The existing laboratory tools are not maintained well resulting in the rusty and damaged tools (Anggereni \& Ikbal, 2018). This school also does not have any vector teaching aids.

This is supported by several important studies on the use of practical tools in learning, including the development of science process skills (M. Maharani, Wati, $\&$ Hartini, 2017), the use of vector devices in vocational middle schools to improve conceptual understanding (Irsyadsyah \& Prabowo, 2015; Muzaky \& Handhika, 2015) use of fluid-static devices learning model (Prihatiningtyas \& Putra, 2018), development of practical tools on wave material (Widayanti \& Yuberti, 2018) and the development of circular motion material teaching aids (Desy, Desnita, \& Raihanati, 2015).

Based on the problems stated, this research differs from the previous ones in terms of the material that utilizes simple materials around the environment. It is hoped is that the application of vector practicum tools can improve students' understanding of concepts. 


\section{METHOD}

This study used research and development (R \& D) methods. Research and Development is research using a method to produce a particular product. Before being a feasible product, the teaching aids have gone through the stages included in the Research and Development method. This research modified the stages proposed by (Sugiyono, 2015). There are only nine stages since mass production have not been done yet. The stages of development are illustrated in figure 1 .

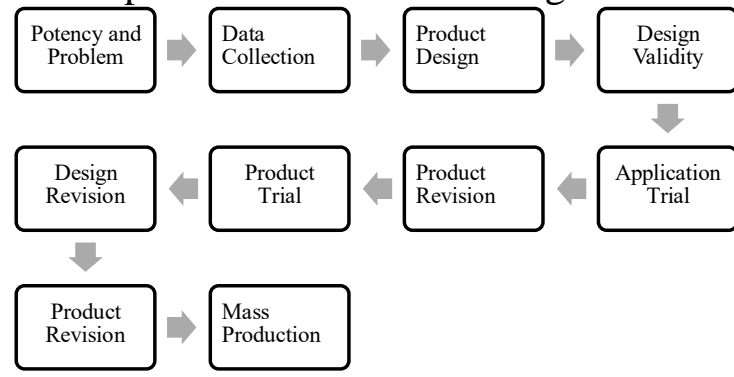

Figure 1. Development Procedure of Resultant Force Vector Teaching Aids

The product developed by this research is in the form of teaching aids so that to determine the effectiveness of the teaching aids, they were tested using the experimental method, namely Group Design Pretest-Posttest. The research design was divided into two groups namely control and experimental group. Both groups were given a pretest to determine the initial state of the students before being given treatment. While after being given treatment, the students were given a posttest to determine the state of the students after the treatment. The following is an overview of the research design used in this research(Sugiyono, 2015).

Table 1. Research Design

\begin{tabular}{cccc}
\hline Classes & Pretest & $\begin{array}{c}\text { Treat- } \\
\text { ment }\end{array}$ & $\begin{array}{c}\text { Post- } \\
\text { test }\end{array}$ \\
\hline Control & $\mathrm{O}_{1}$ & $\mathrm{X}_{1}$ & $\mathrm{O}_{2}$ \\
Experiment & $\mathrm{O}_{3}$ & $\mathrm{X}_{2}$ & $\mathrm{O}_{4}$ \\
\hline
\end{tabular}

$\mathrm{O}_{1}$ : Score of the control class pretest

$\mathrm{O}_{2}$ : Score of the control class posttest
$\mathrm{O}_{3}$ : Score of the experiment class pretest

$\mathrm{O}_{4}$ : Score of the experiment class posttest

$\mathrm{X}_{1}$ : Treatment of the vertical vector teaching aids used directly by the students

$\mathrm{X}_{2}$ : Treatment of the resultant force vector teaching aids used directly by the students

The research was done in September 2018 at 1 Subah Senior High School, Batang Regency. The sample in this research is the tenth grade of natural science class at 1 Subah Senior High School. The sampling technique used simple random sampling.

Data collection techniques in this research were observation, questionnaires, and tests. The observation was used to determine the existing conditions and problems at the school. The questionnaire was used to determine the feasibility of the resultant force vector teaching aids done by 2 validators, namely the physics teachers at 1 Subah Senior High School.

The tests used were pretest and posttest to find out the results of the improvement in students' conceptual understanding before and after using the teaching aids.

The research data were processed using the teaching aids' feasibility test, hypothesis test, $\mathrm{N}$-gain test, and students' response questionnaire test. The teaching aids' feasibility test was to find out the feasibility of the teaching aids before being used for the research. Hypothesis test was done to determine the influence of the teaching aids on the students' conceptual understanding, $\mathrm{N}$-gain test was done to determine the magnitude of the students' conceptual understanding and students' response questionnaire analysis.

The teaching aids' validity test was to find out the validity of the teaching aids, whether they are feasible to use or not at the time of research. The percentage criteria for the validity level are as follows (Saregar, Zubaedi, Parmin, Jamaludin, \& Septiani, 2019; Sugiyono, 2014): 
Table 2. Percentages of the Validity Levels

\begin{tabular}{cll}
\hline No. & Percentages & Categories \\
\hline 1. & $80 \%<$ Score $\leq 100 \%$ & Very feasible \\
2. & $60 \%<$ Score $\leq 80 \%$ & Feasible \\
3. & $40 \%<$ Score $\leq 60 \%$ & Enough feasible \\
4. & $20 \%<$ Score $\leq 40 \%$ & Less feasible \\
5. & $0 \%<$ Score $\leq 20 \%$ & Not feasible \\
\hline
\end{tabular}

The hypothesis test data collection technique was conducted to find out whether there was an effect of learning using 4 resultant force vector teaching aids and 2 vertical vector teaching aids.
To find out the effects on learning, SPSS 22.0 hypothesis test criteria according to (Rosnita, 2015), they can be seen in Table 3 as follows:

Table 3. Independent T-Test Hypothesis Criteria

\begin{tabular}{llc}
\hline \multicolumn{2}{c}{ Ranges } & \multicolumn{1}{c}{ Categories } \\
\hline 1. & Significant $(2$-tailed $)<0,05$ & $\mathrm{H}_{0}$ refused $\mathrm{H}_{\mathrm{a}}$ accepted \\
2. & Signifikansi $(2$-tailed $)>0,05$ & $\mathrm{H}_{0}$ accepted $\mathrm{H}_{\mathrm{a}}$ refused \\
\hline
\end{tabular}

Data collection techniques for $\mathrm{N}$-gain test were measured from the scores of the pretest and posttest of the experimental class and control class students, $\mathrm{N}$-gain criteria according to (Rosnita, 2015) can be seen in Table 4 as follows:

Table 4. N-gain $<\mathrm{g}>$ Criteria

\begin{tabular}{ccc}
\hline No & $\langle$ g $>$ Score & Categories \\
\hline 1. & $0,3<\mathrm{g}$ & Low \\
2. & $0,3 \leq \mathrm{g}<0,7$ & Moderate \\
3. & $0,7 \leq \mathrm{g}$ & High \\
\hline
\end{tabular}

Based on the data collection obtained by filling out the questionnaire by the experimental class students who had used the resultant force vector teaching aids to find out the criteria for the questionnaire results, they can be seen in Table 5.

Table 5. The Students' Responses Questionnaire Criteria

\begin{tabular}{lcl}
\hline No. & Percentages & \multicolumn{1}{c}{ Criteria } \\
\hline 1. & $0 \% \leq$ Score $<25 \%$ & Low \\
2. & $25 \% \leq$ Score $<50 \%$ & Moderate \\
3. & $50 \% \leq$ Score $<75 \%$ & High \\
4. & $75 \% \leq$ Score $<100 \%$ & Very High \\
\hline
\end{tabular}

\section{RESULTS AND DISCUSSION}

From the problems based on the observations, the researcher developed a simple teaching aid able to support the learning process in the classroom. The researcher developed the teaching aids to determine the resultant force in vector material. These teaching aids had been developed by (Irsyadsyah \& Prabowo,
2015), the developed teaching aids got the feasibility test of $88.33 \%$ included in the category of very feasible to use. However, these teaching aids still have some disadvantages and the balance of this teaching aid can also be used for vector material.

The development of the resultant force vector teaching aids had been 
validated by the experts, these results can be seen in Table 6 with an average percentage of $98.61 \%$, included in the very feasible category to be used. These results showed that the propeller of the resultant force vector is better than that developed by (Irsyadsyah \& Prabowo, 2015).

Some of the components developed in the resultant force vector teaching aids, the design is as follows:

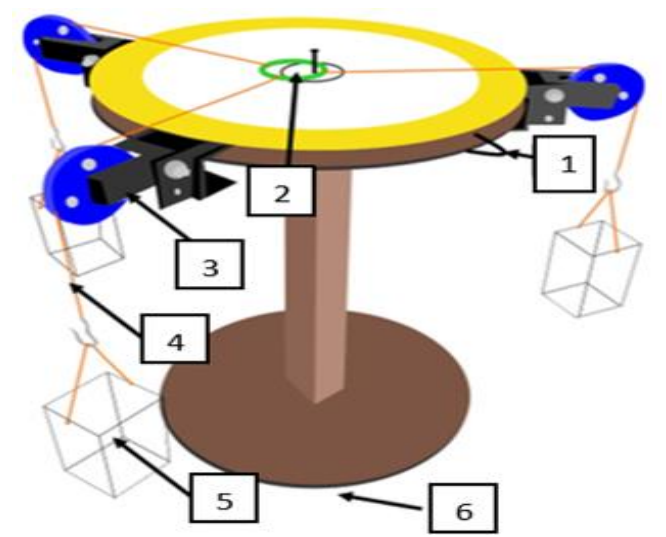

Figure 2. Design of resultant force vector teaching aids

1. Giving distance for laying the pulley. In providing this distance, it uses plywood material, which is stacked with three plywoods. Two 25$\mathrm{cm}$ plywoods with 5-mm thickness and one plywood are located between two plywoods with the same diameter of $17 \mathrm{~cm}$ and different thickness of 12$\mathrm{mm}$. In the development carried out by (Irsyadsyah \& Prabowo, 2015) for the placement of pulley and arc.
2. Ring. Minimize the ring with a diameter of $2.5 \mathrm{~cm}$ functioning as a measuring instrument to see the load balance.

3. Pulley. The placement of pulleys or wheels made of acrylic material is different from the development carried out by (Irsyadsyah \& Prabowo, 2015). The developed pulley is a pulley that can change the height of the pulley to reduce parallax while viewing angles.

4. Rope. The rope used is a fishing rope with a $0.3-\mathrm{mm}$ thickness to reduce the friction force between the pulley and the rope.

5. Sand load. In the development of the resultant force vector teaching aids carried out by (Irsyadsyah \& Prabowo, 2015) using loads that had been known for their weight, which would make the practice using a limited mass. The developed resultant force teaching aids of uses the sand load as the weight of the mass.

6. PVC and Rubber. In this development, it put 3 legs used with PVC and rubber so that the teaching aids do not shake.

The design of the teaching aids can be disassembled because these tools use nuts and bolts that will make it easier to carry, store and technical use of the resultant force vector teaching aids is very easy to operate, namely by rotating the pulley and inserting the sand into the load place slowly until it looks balanced.

Table 6. Feasibility Analysis Results

\begin{tabular}{|c|c|c|c|c|c|c|}
\hline \multirow[b]{2}{*}{ No. } & \multirow[b]{2}{*}{ Components } & \multicolumn{3}{|c|}{ Scores } & \multirow[b]{2}{*}{ Total } & \multirow[b]{2}{*}{ Percentage } \\
\hline & & Lecturer & $\begin{array}{l}\text { Teacher } \\
\text { I }\end{array}$ & $\begin{array}{l}\text { Teacher } \\
\text { II }\end{array}$ & & \\
\hline 1. & Practicality & 4 & 4 & 4 & 12 & $100 \%$ \\
\hline 2. & Usefulness & 4 & 4 & 4 & & \\
\hline 3. & $\begin{array}{l}\text { Showing the phenomena and } \\
\text { accurate result }\end{array}$ & 4 & 4 & 4 & 12 & $100 \%$ \\
\hline 4. & Concept conformity & 4 & 4 & 4 & 12 & $100 \%$ \\
\hline 5. & Construction & 3 & 4 & 4 & 11 & $91,67 \%$ \\
\hline 6. & Economicality & 4 & 4 & 4 & $\begin{array}{c}12 \\
\text { verage }\end{array}$ & $\begin{array}{c}100 \% \\
98,61 \%\end{array}$ \\
\hline
\end{tabular}


Before the research, the teaching aids were validated in advance by the experts, this validation was used to provide a feasibility score for the developed resultant vector teaching aids, the results of validation by three validators, namely one lecturer and two teachers at 1 Subah Senior High School can be seen in Table 6.

The developed teaching aids were carried out to refine the teaching aids that had been developed previously.

After obtaining the teaching aids' validation, the teaching aids were used by 1 Subah Senior High School students, to find out the improvement of students' learning and response to the use of teaching aids in the classroom. The use of 4 resultant force vector teaching aids (horizontal vector teaching aids) for the experimental class namely the tenth grade of 3 natural science class (X IPA 3), while for 2 vertical vector teaching were used for the control class namely the tenth grade of 4 natural science class (X IPA 4).

Before the use of teaching aids, students had gotten vector material starting from the definition of vectors, how to write, how to describe, add, subtract, graphical methods and methods of analysis

The two teaching aids were used directly by students in groups consisting of 9 students in one group. Before being given treatment, the students were given a pretest to find out the initial state of the students. Before the use of the teaching aids and pretest, the students had gotten vector material starting from the definition of vectors, how to write, how to draw, addition, subtraction, parallelogram method and method of analysis. After receiving the material, the students were given a pretest. The results of the students' pretest of the experimental class and the control class can be seen in Table 7 .
Table 7. The Students' Pretest Results

\begin{tabular}{|c|c|c|c|}
\hline No & Data & Experiment & Control \\
\hline 1 & $\begin{array}{l}\text { Number of } \\
\text { students }\end{array}$ & 36 & 36 \\
\hline 2 & The highest score & 75 & 75 \\
\hline 3 & The lowest score & 25 & 30 \\
\hline 4 & Mean & 48,06 & 48,54 \\
\hline 5 & $\begin{array}{l}\text { Standard } \\
\text { deviation }\end{array}$ & 12,29 & 11,20 \\
\hline
\end{tabular}

From Table 7, it can be concluded that the average score of the pretest of the experimental class and the control class before being given treatment had almost the same score. This is because the researchers were still using the lecture method in explaining the material presented to students.

To support effective and interesting learning in the classroom, the teaching aids were used. Learning using teaching aids such as practicing was carried out in the experimental class namely the tenth grade of 3 natural science class (X IPA 3) and the tenth grade of 4 natural science class (X IPA 4) as the control class. The number of given teaching aids was 4 pieces of the resultant force teaching aids for the experimental class, while for the control class, 2 vertical vector teaching aids were given. The researchers formed the students into 4 groups consisting of 9 students for each group.

After the division of the group, the researchers provided tools and materials for teaching aids to each group and guidance or direction to students before they used the teaching aids. The researchers gave students time to read the Student Worksheets and give time to ask some questions before the use of teaching aids. The researcher asked the students to record each load and every angle formed on each load. After everything was clear, the researcher gave time to the students to start taking data. The students took more than 5 data. at the time of analyzing the data, the students could choose the best data. 
When the practice took place for the experimental class, the researcher guided the students to practice, each group carried out good practice with no obstacles. In the third data retrieval, the students took data with angles and mass loads that were almost the same because the mass they filled was sand by using a long time to wait for the load to be balanced. The balance was seen from the ring bound to the rope.

At the practice in the control class, due to the limited mass of the load and the use of teaching aids alternated with the other groups so as to make students take data with angles and mass loads that were almost same. At the practice, the students were eager to get the data and there was no difficulty in each group in doing the practice.

After the students get the data, they were asked to process data and answer existing questions at Student Work Width, then presenting in front of the class. Both classes were given posttest to find out the difference after being given treatment, the results can be seen in Table 8 .

Table 8. The Students' Posttest Results

\begin{tabular}{|c|c|c|c|}
\hline No & Data & Experiment & Control \\
\hline 1 & $\begin{array}{l}\text { Number } \\
\text { students }\end{array}$ & 36 & 36 \\
\hline 2 & The highest score & 100 & 100 \\
\hline 3 & The lowest score & 45 & 45 \\
\hline 4 & Mean & 82,2 & 71,39 \\
\hline 5 & Standard deviation & 12,29 & 11,20 \\
\hline
\end{tabular}

Table 8 shows the results of the students' posttest scores after getting treatment, the two classes got an average score that increased from the average score of the pretest. The increase in the average score was due to the given treatment, by providing teaching aids used directly by students, which made students active in the classroom. The use of teaching aids also provided a real experience to students able to motivate the students to learn. With the use of teaching aids, students were able to improve their conceptual understanding measured from the learning outcomes and produced information for independent learning. This is in line with research conducted by (Muzaky \& Handhika, 2015), with experimental methods able to improve the cognitive outcomes of the students.

The magnitude of the increase in conceptual understanding of the experimental class and the control class students was tested using the students' pretest and posttest scores that can be seen in Table 9.

Table 9. N-gain Test Results

\begin{tabular}{lccc}
\hline \multicolumn{1}{c}{ Class } & $\begin{array}{l}\text { Pretest } \\
\text { Mean }\end{array}$ & $\begin{array}{c}\text { Posttest } \\
\text { Mean }\end{array}$ & Gain \\
\hline $\begin{array}{l}\text { Experi- } \\
\text { ment }\end{array}$ & 48,06 & 82,20 & 0,7 \\
Control & 48,54 & 71,39 & 0,4 \\
\hline
\end{tabular}

Table 9 shows the increase after getting treatment. Improved students' conceptual understanding was measured from the results of the pretest to the students' posttest; the increase produced a $0.7 \mathrm{~N}$-gain value included in the high category for the experimental class. It can be concluded that the use of teaching aids directly and in groups can provide a good conceptual understanding. This is in line with the results of (Pramesty \& Prabowo, 2013) that the use of teaching aids was able to provide an increase in students' conceptual understanding in the experimental class. The statement is also supported by (Psycharis, 2016).

The Improvement of the conceptual understanding of the control class also used students' scores from the results of the students' pretest to posttest. The increase results in a $0.4 \mathrm{~N}$-gain value included in the moderate category.

The use of teaching aids in the experimental class and the control class in groups could provide an increase in students' conceptual understanding and the students' activities in the classroom so as to provide experienced learning to the students that will last a long time in students' memories (Jiniarti, Sahidu, \& Verawati, 2017). However, the use of the 
teaching aids in the classroom was less optimal and required a long time, causing students to rush into data collection in practice so that it could interfere with students' conceptual understanding. This is in line with (Swandi, Hidayah, \& Irsan, 1996) who understood that the practice speed will interfere with the students' conceptual understanding.

Based on hypothesis test using SPSS 22.0 with a paired sample t-test, the results of significance were 0.000 , which means that it was smaller than 0.05 . Then Ho is rejected and $\mathrm{Ha}$ is accepted. From these results, it can be concluded that the resultant force vector teaching aids can improve the students' conceptual understanding.

Students' responses to the use of the resultant vector teaching aids in the experimental class were obtained from questionnaires. The results of the questionnaire showed that the students' attitudes towards the use of vector teaching aids were $71 \%$ included in the good category, the responses of the students in this attitude category showed that the use of vector teaching aids could be accepted by students. For the results of the questionnaire in the interest category, it was $70.48 \%$, included in the high category, the use of teaching aids in the classroom was able to provide high interest in students to carry out the learning with the use of the teaching aids. While the results of the questionnaire in the category of attraction were $71.70 \%$, included in the high category, the use of teaching aids was able to provide the attractiveness of students in learning in the classroom so as to facilitate students in solving a problem (Alvian, Yulianto, \& Subali, 2017). This is also in line with (Holubova, 2015) mentioning that the students can be motivated in physics learning by getting experience, applying natural science in everyday life, and using a learning media utilizing the modern technology.

\section{CONCLUSIONS AND SUGGESTION}

Based on the results of this study, it can be concluded as follows: (1) the feasibility test of the resultant force vector teaching aids produces a percentage of $98.61 \%$, included into very feasible to use category. (2) the use of resultant force vector teaching aids can improve the students' conceptual understanding with the increase of 0.7 , included in the high category. (3) the students' responses to the use of the resultant force vector teaching aids get an average percentage of $71.06 \%$, included in the high category.

The researchers suggested the schools use learning methods by applying experienced learning such as experiments able to generate the students' activities and provide motivation directly to students.

\section{REFERENCES}

Alvian, A., Yulianto, A., \& Subali, B. (2017). Desain Alat Peraga Digital Image Creator For Optical Microscope (DIGICOM) dalam Pembelajaran IPA untuk Menumbuhkan Motivasi Belajar Siswa. UPEJ Unnes Physics Education Journal, 6(3), 32-37. https://doi.org/10.15294/UPEJ.V6I3. 19312

Anggereni, S., \& Ikbal, M. S. (2018). Analysis Of Physics Laboratory Management At The Northern Region Of Makassar's State Senior High Schools By Standard Of Facilities And Infrastructure. Jurnal Ilmiah Pendidikan Fisika Al-BiRuNi, 7(1), 41-47.

https://doi.org/10.24042/jipfalbiruni.v 7i1.2329

Anwar, C., Saregar, A., Yuberti, Y., Zellia, N., Widayanti, W., Diani, R., \& Wekke, I. (2019). Effect Size Test of Learning Model ARIAS and PBL: Concept Mastery of Temperature and Heat on Senior High School Students. Eurasia Journal of Mathematics, Science and Technology Education, 
15(3), 1-9.

https://doi.org/10.29333/ejmste/1030 32

Berszán, I. (2016). Empirical Research and Practice-oriented Physics for the Humanities and Sciences. Comparative Literature and Culture, 18(2).

Billah, A., \& Widiyatmoko, A. (2018). The Development of Virtual Laboratory. Jurnal Ilmiah Pendidikan Fisika AlBiruni, 7(2), 153-160.

Desy, D., Desnita, D., \& Raihanati, R. (2015). Pengembangan Alat Peraga Fisika Materi Gerak Melingkar untuk SMA. Prosiding Seminar Nasional Fisika (E-Journal) SNF2015, 4, 3944.

Gire, E., \& Price, E. (2014). Arrows as anchors: An analysis of the material features of electric field vector arrows. Physical Review Special Topics Physics Education Research, 10(2), $1-11$.

Girvan, C., Conneely, C., \& Tangney, B. (2016). Extending Experiential Learning in Teacher Professional Development. Teaching and Teacher Education, 58, 129-139.

Handhika, J., \& Kurniadi, E. (2016). Peningkatan Hasil Belajar Mahasiswa Pokok Bahasan Analisis Vektor Melalui Inkuiri Terbimbing. Jurnal Pendidikan Fisika Dan Keilmuan (JPFK), 2(1), 12-15.

Holubova, R. (2015). How to Motivate our Students to Study Physics? Universal Journal of Educational Research, $3(10)$, 727-734. https://doi.org/10.13189/ujer.2015.03 1011

Irsyadsyah, M., \& Prabowo. (2015). Pengembangan Alat Peraga Resultan Gaya Sebagai Media Pembelajaran Fisika Materi Pokok Kesetimbangan Partikel. Jurnal Inovasi Pendidikan Fisika, 4(2), 45-49.

Jiniarti, B. E., Sahidu, H., \& Verawati, N. N. S. P. (2017). Implementasi Model
Problem Based Learning Berbantuan Alat Peraga untuk Meningkatkan Aktivitas dan Hasil Belajar Fisika Siswa Kelas VIII SMPN 22 Mataram Tahun Pelajaran 2014/2015. Jurnal Pendidikan Fisika Dan Teknologi, 1(3), 185. https://doi.org/10.29303/jpft.v1i3.257

Korsun, I. (2017). The Formation of Learners' Motivation to Study Physics in Terms of Sustainable Development of Education in Ukraine. Journal of Teacher Education for Sustainability, 19(1), 117-128.

Kusuma Wardani, I. (2016). Pengaruh Pemahaman Konsep Matematika Vektor Mahasiswa FMIPA Unipdu Terhadap Kemampuan Pemecahan Masalah Fisika Mekanika. Jurnal Pedagogia, 5(2).

Maharani, L., Rahayu, D. I., Amaliah, E., Rahayu, R., \& Saregar, A. (2019). Diagnostic Test with Four-Tier in Physics Learning: Case of Misconception in Newton's Law Material. Journal of Physics: Conference Series, 1155(1), 012022. https://doi.org/10.1088/17426596/1155/1/012022

Maharani, M., Wati, M., \& Hartini, S. (2017). Pengembangan Alat Peraga pada Materi Usaha dan Energi untuk Melatihkan Keterampilan Proses Sains melalui Model Inquiry Discovery Learning (IDL) Terbimbing. Berkala Ilmiah Pendidikan Fisika, 5(3), 351-367.

Muzaky, A. F., \& Handhika, J. (2015). Penggunaan Alat Peraga Sederhana Berbasis Teknologi Daur Ulang untuk Meningkatkan Pemahaman Konsep Materi Vektor dalam Kelas Remedial SMKN 1 Wonoasri Tahun Pelajaran 2014/2015. In Prosiding Seminar Nasional Fisika dan Pendidikan Fisika (SNFPF) (129-134).

Okono, E. O. (2015). Experimental Approach as a Methodology in Teaching Physics in Secondary 
Schools. In International Journal of Academic Research in Business and Social Sciences (388-406).

Pramesty, R. I., \& Prabowo, P. (2013). Pengembangan Alat Peraga KIT Fluida Statis Sebagai Media Pembelajaran Pada Sub Materi Fluida Statis di Kelas XI IPA SMA Negeri 1 Mojosari, Mojokerto. Inovasi Pendidikan Fisika, 2(3), 70-74.

Prihatiningtyas, S., \& Putra, I. A. (2018). Efektivitas Penggunaan Alat Peraga Sederhana Berbasis Pendekatan Sains Teknologi Masyarakat pada Materi Fluida Statis. JRKPF UAD, 5(9), 102107.

Psycharis, S. (2016). Inquiry basedcomputational experiment, acquisition of threshold concepts and argumentation in science and mathematics education. Educational Technology and Society, 19(3), 282293.

Rosnita, S. (2015). Statistik Penelitian Pendidikan. Bandung: Alfabeta.

Saregar, A., Zubaedi, Parmin, Jamaludin, W., \& Septiani, R. (2019). Feasibility Test of Mobile Learning with Schoology: Efforts to Foster The Students' Learning Interest on Magnetism. Journal of Physics: Conference Series, 1155(1), 012060. https://doi.org/10.1088/17426596/1155/1/012060

Smith, T. I., Wittmann, M. C., \& Carter, T. (2014). Applying model analysis to a resource-based analysis of the Force and Motion Conceptual Evaluation. Physical Review Special Topics Physics Education Research, 10(2), $1-17$.

Sugiyono. (2014). Metode Penelitian Kuantitatif, kualitatif dan $R \& D$. Bandung: Alfabeta.

Sugiyono. (2015). Metode Penelitian Pendidikan Pendekatan Kuantitatif, Kualitatif dan $R \& D$. Bandung: Alfabeta.

Sulisworo, D. (2016). The Contribution of the Education System Quality to Improve the Nation's Competitiveness of Indonesia. Journal of Education and Learning, 10(2), 127-138.

Swandi, A., Hidayah, S. N., \& Irsan, L. J. (1996). Pengembangan Media Pembelajaran Laboratorium Virtual Untuk Mengatasi Miskonsepsi Pada Materi Fisika Inti Di SMAN 1 Binamu, Jeneponto. Jurnal Fisika Indonesia UGM, 18(52), 20-24.

Widayanti, Abdurrahman, \& Suyatna, A. (2019). Future Physics Learning Materials Based on STEM Education : Analysis of Teachers and Students Perceptions. Journal of Physics Conferences Series, 1155, 1-9. https://doi.org/10.1088/17426596/1155/1/012021.

Widayanti, \& Yuberti. (2018). Pengembangan Alat Praktikum Sederhana Sebagai Media Praktikum Mahasiswa. JIPFRI (Jurnal Inovasi Pendidikan Fisika Dan Riset Ilmiah), 2(1), 21-27. https://doi.org/10.30599/jipfri.v2i1.16 1.

Wutchana, U., Bunrangsri, K., \& Emarat, N. (2015). Teaching Basic Vector Concepts: A Worksheet for the Recovery of Students' Vector Understanding. Eurasian Journal of Physics and Chemistry Education, 7(1), 18-28.

Zahara, S., Haji, A. G., \& Syukri, M. (2018). Improving the Concept Understanding and Scientific Attitudes through the Implementation of Scientific Approach. Tadris: Jurnal Keguruan Dan Ilmu Tarbiyah, 3(1), 55-66.

https://doi.org/10.24042/tadris.v3i1.2 513 